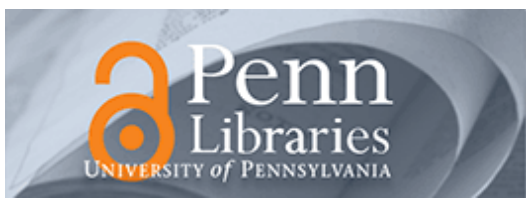

University of Pennsylvania ScholarlyCommons

Department of Anthropology Papers

Department of Anthropology

1965

\title{
Arghiyān: The Area of Jājarm in Western Khurāsān
}

Brian Spooner

University of Pennsylvania, spooner@sas.upenn.edu

Follow this and additional works at: http://repository.upenn.edu/anthro_papers

Part of the Anthropology Commons

\section{Recommended Citation}

Spooner, B. (1965). Arghiyān: The Area of Jājarm in Western Khurāsān. Iran, 3 97-107. Retrieved from http://repository.upenn.edu/ anthro_papers/137

This paper is posted at ScholarlyCommons. http://repository.upenn.edu/anthro_papers/137

For more information, please contact libraryrepository@pobox.upenn.edu. 


\section{Arghiyān: The Area of Jājarm in Western Khurāsān}

\section{Disciplines}

Anthropology | Social and Behavioral Sciences 


\title{
ARGHIYĀN ${ }^{1}$ \\ The area of Jājarm in western Khurāsān
}

\author{
By Brian Spooner
}

\section{Introduction}

The extreme west of Khurāsān, whether we think of the present ustān or the historical province, has never contained a large city. Between Sabzavār, the Gurgān Plain and Basțām (or Shāhrūd) has always been relatively empty border country between Khurāsān and the central provinces. In the north are the mountains, which separate the plateau from the Qara Qum, and the Atrak corridor. In the south lies the Great Kavir. But between these stretches a long, narrow plain, which because of its position has naturally formed throughout its history a channel for east-west traffic. The routes through this plain have depended naturally on the position and prosperity and decline of the cities they serve outside it. The plain itself has never contained anything approaching the size of a provincial capital, and the settlements which it does contain have shared the vicissitudes of the cities served by the roads which pass through them.

The main names in this plain are reasonably well known: Juvain, Isfarāyin and Jājarm. The first two are the names of regions, although the second is now the name of the main town in its region, which is a not unusual development. ${ }^{2}$ It is therefore unusual that the town of Jäjarm (according to Sani'ud'Dauleh in the Mațla'u'sh-Shams, I 30 I A.H., a corrupt form of $\mathcal{F} \bar{a}-i$ garm - " the hot place") should have remained Jājarm, and the old name of the region-Arghiyān, often found in pre-Mongol writings, should have died out, for the writer knows of no mention of it since Rashidu'd-Din ( $1306-1$ I).$^{3}$ However, as there is no other name which implies the region, $I$ have retained it in this article.

The plain has always formed a hinterland of whichever of the surrounding cities has been most flourishing. For example, it was dependent on Nishāpūr in the first five centuries of Islam, and on Sabzavār under the Sarbadār dynasty. At present, it is divided between Sabzavār, Shāhrūd and Bujnurd.

From a modern study of the area it would appear that the most likely reason for there never having been a large centre of population in the plain, particularly in Arghiyān, is lack of water. If the history of Persia is the history of areas, it is relevant to divide the areas into independent and dependent. Cities such as Nishāpūr or Gurgān, though the size of their respective cities has varied greatly, have always retained a sufficient pull over the surrounding countryside to be regarded as relatively independent, local, economic and political units; whereas our plain, lacking the water supply for a large city and deriving major economic benefit from long-distance traffic, must always be dependent on a neighbouring independent area. ${ }^{3 \mathrm{a}}$

Sources for the history of the plain are for the most part scrappy and vague. There are many references, but most of them inform us simply (in the histories) that so-and-so passed through, or (in the geographies) give a subjective impression that such-and-such a village is prosperous, or such-andsuch an area has so many villages-when we know neither the writer's criterion of prosperity nor the

\footnotetext{
1 The substance of this article formed part of a lecture delivered at the British Institute of Persian Studies in Tehran in December 1962. The purpose of the lecture was to demonstrate how scholars from different disciplines working together in the field and the library could contribute towards the knowledge and understanding of an area-an ecological unit. The reason for the choice of the particular region treated in this article is due simply to the writer's familiarity with it. Among the several people who have contributed to discussions on the ideas here presented I should like in particular to thank Mr. R. M. Rehder.
}

2 Cf. Gunābād for Jūymand, Darreh Gaz for Muḥammadābād, Sīrjān for Sa 'īdābād, Jīruft for Sabzavārān, and even Khurāsān for Mashhad in modern usage.

3 History of Ghazan Khan, ed. Karl Jahn, E. J. W. Gibb Memorial New Series XIV, 1940, pp. 23, 28.

3a Cf. The areas of Sar-i Kavir (Rishm and Husainān) South of Dāmghān, and Biyābānak (Khūr and Jandaq) North East of Nâ'in which have been dependent administratively at various times on each of the cities which border on the western half of the great Kavir: Yazd, Nā'in, Tehrān, Simnān, Shāhrūd. 
extent of the area which contained that number of villages. It is true that a close critical study and collation of all these references might yield more evidence for the economic condition and political dependence of the plain at certain periods, but it is unlikely that such evidence would be definitive, and the aim of this article is simply to outline general trends of prosperity and decline and ecological dependence, and to point out features which may prove typical in the historical ecology of Persia. The historical sources cited are therefore confined to those with more direct relevance to the condition of the plain. It is noteworthy that the length of references generally increases as the degree of prosperity apparently declines, but this is most likely due to the fact that writers in the first centuries of Islam treated the world, whereas in the nineteenth century they were dealing with only a very much diminished Iran.

\section{Geographical}

The plain stretches in a wide arc from Basțām in the west to within roo kilometres of Nishāpūr in the east. It is nearly 200 miles long and something under forty miles across at its widest point. It falls traditionally into four distinct divisions separated by natural features. These natural features have been regarded as boundaries throughout history and are the basis of present-day administrative divisions. The western end of the plain once centred on Bastām and belonged to the mediaeval province of Qūmis. Today it belongs to the shahristān (sub-province) of Shāhrūd which is part of the independent governorship ( farmāndārí-i kull) of Simnān. It is the most desert and least important part of the plain, containing only the bakhsh of Mayāmay, which consists of Mayāmay itself under the mountain of the same name and the Kalät-hā-a group of small villages-down in the plain. This section of the plain drains eastwards and either side of the line of drainage is a strip of treacherous soft salt earth, such as is normally referred to as " kavir ", and by the local people-c "lüt". The Kāl-i Shūr, for the most part of the year sluggish, meagre and highly saline, flows from the north-east corner of the plain to the centre where it turns south and cuts deep into the plain with salt flats extending up to half a mile on either side of it. It collects the drainage from the other parts of the plain and aims straight for the Kavir proper, at the north of which it passes under the Pul-i Abrisham-the Bridge of Silk, which traditionally divides Qūmis from Khurāsān. The present-day bridge appears quite new, but Curzon's picture of it looks identical and he observes that it was built by Nādir Shāh and restored not long before he passed over it in I889. The Bridge is mentioned at the end of the fifteenth century in the History of Herăt. ${ }^{4}$ Today the new railway bridge over the Kāl-i Shūr seems to have usurped the name. Neither bridge is any longer justified by the trade in silk, and it is interesting that Pul-i-äb-i raushan is heard as an alternative name.

Of the remainder of the plain the southern part is a long, comparatively narrow corridor known as Juvain and famed in the middle ages for its fertility, its 400 villages, each with one or two qanäts which never failed. 5 The corridor drains westwards into the Kāl-i Shūr but there is no river bed to take the surplus water and at certain seasons of the year a swamp forms at the lower end of the plain which cuts off motorized communication between Jäjarm and the railway. Juvain is the most fertile section of the whole plain, and is historically the best known. It is traditionally a part of the old province of Baihaq which lies on the other side of the Jughatāy mountains, and is today dependent on Sabzavār. The name Juvain is (according to Yāqūt, I 224 A.D.) an arabized form of Gūyān, which was the old name of the district. The main town has been variously Āzādvār, Furūmad (which is strictly speaking not in Juvain at all), and is now Jughatāy.

North of the Juvain corridor and separated from it by a low ridge lies the plain of Isfarāyin, also very fertile and well known in particular for its fruit. The proper name of the main town is Miyānābād. An earlier town on this site appears to have borne the name Mihrajān. ${ }^{6}$ IsfarāyIn is at present an independent shahristān in the province of Khurāsān, but until the visit of then prime minister Iqbāl in 1958, it belonged to the shahristän of Bujnurd.

West of Isfarāyin and north-west of Juvain in a bay in the mountains and commanding a pass to

4 Rauzāt-al Jannāt fi Awsāf-i Madinat-i Herät, University of ${ }^{5}$ Qazvinī, Äthāru'l-Biläd, Beirut, 196o, p. 352.

Tehrān I 339, part 2, pp. I42, 145, 353.

- Yāqūt, Mu'jamu'l-Buldān, Beirut, I955, vol. I, p. 177. 


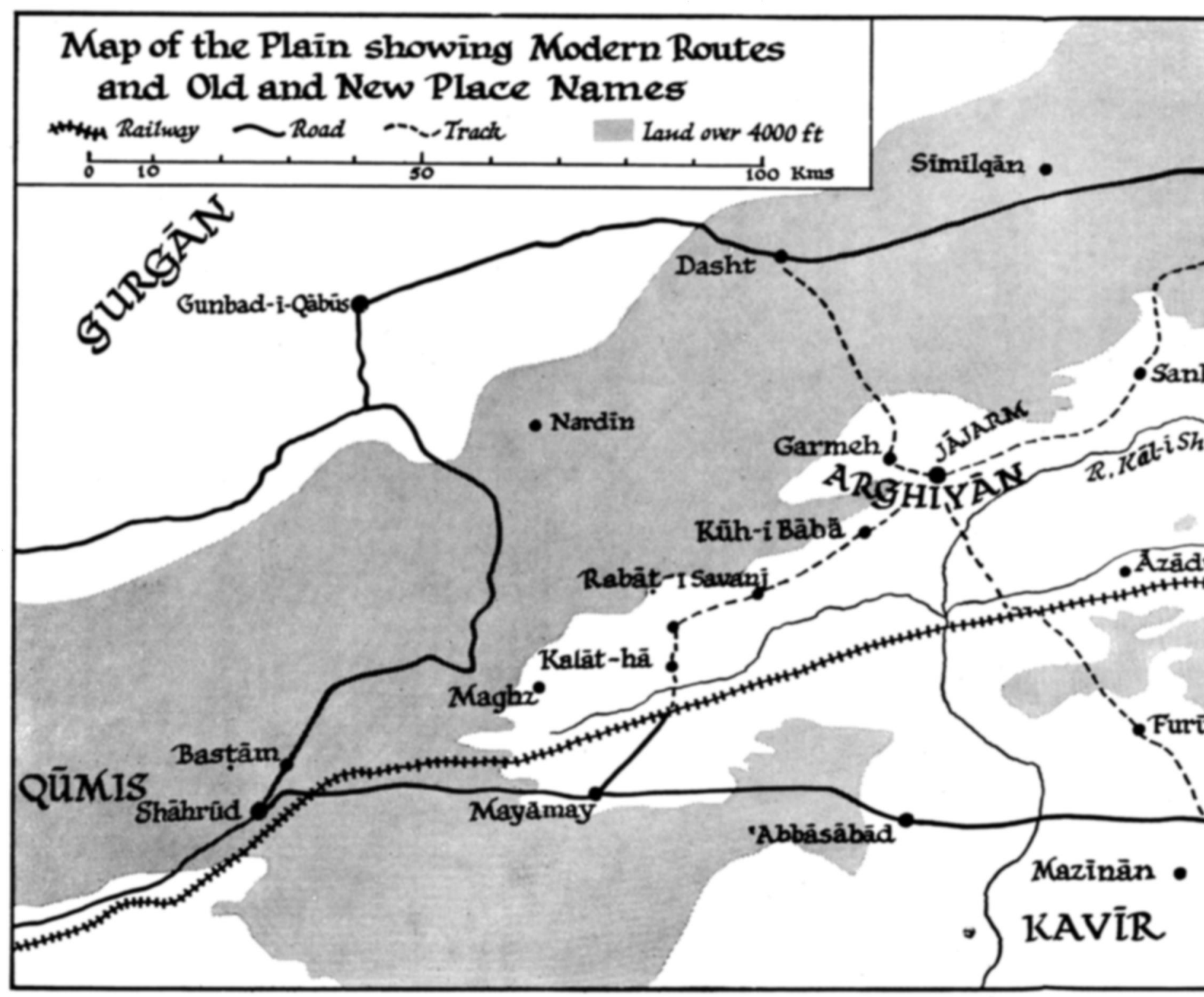

facing page 98.] 


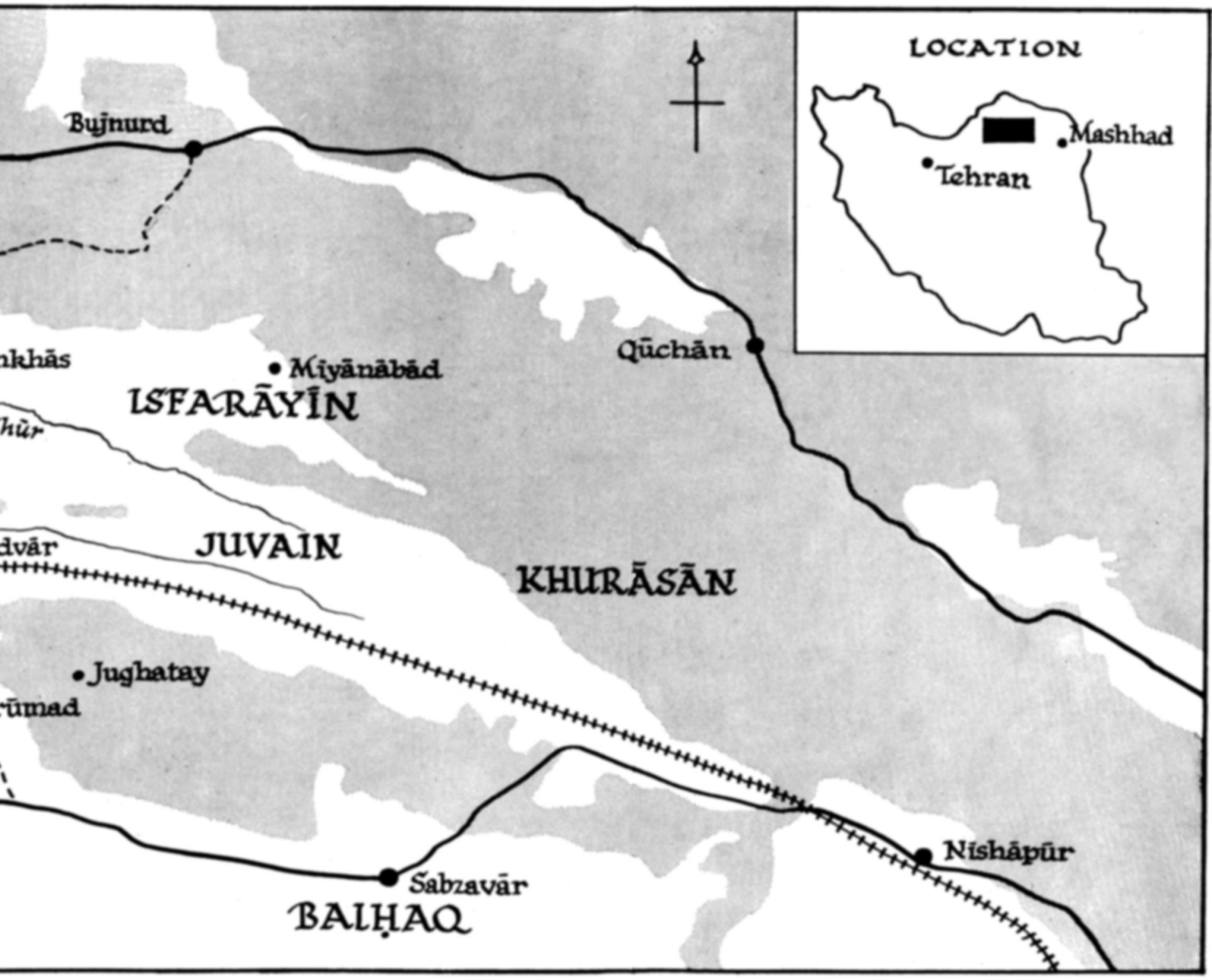

ig. $I$. 
Gurgān and the north-west lies the smallest of the four divisions of the plain, isolated from the other three by the pattern and the nature of the drainage of the whole plain. The main town is Jajarm, which is the centre of a bakhsh which stretches north-west up to the main northern road and the pass which leads down on to the Gurgān plain, and north-east past Sankhāṣ about half way through the mountains on the way to Bujnurd. This was the district of Arghiyän, though it is not known how far it extended northwards when the name was in use.

It is in this last division that I am primarily interested. A quick glance at the town today suggests that it is now only a shadow of its former self, for it is surrounded by the remains of ruined walls. In its present situation it stands on the edge of saline ground which slopes away very gently towards the Kāl-i Shūr, about five miles away to the south-east. This circumstance allows it to draw its water supply from the north and west only. There are the ruins of four considerable forts or fortified villas within the area of the present town, one of which stands on a high steep-sided mound in the centre of the older part of the town. An even more substantial fort known as Qal'eh-i Jalālu'd-Din may be seen three miles away to the north-west on an isolated hill which overlooks the entrance to the pass which leads to Nardjn and the Gurgān plain. Jājarm in fact guarded two important ways of access to the Persian plateau. When Persia's north-eastern border was less definite, or when the Turkoman were raiding, this was an important consideration, but it is no longer so, and this shows us one reason for the decline in the importance of the town.

About three-quarters of a mile to the south of Jajarm a long low mound stretches about two kilometres in an east-west direction. It is locally known as Tappeh-i Pahlavãn and yields mostly Islamic pottery. Further south, and approximately two-and-a-half miles from the town lies another mound of a more interesting nature: for it gives the appearance of a small high mound with a fortification wall, and a large proportion of its pottery is painted, chalcolithic, suggesting occupation of one period only, probably in the fourth millennium B.c. ${ }^{7}$ The first of these mounds at present marks the southern limit of cultivation around Jajarm. The second is completely without vegetation and surrounded only by the sparsest desert scrub, leaving no easy answer to the question as to how it once obtained a sufficient water supply. The presence of these mounds suggests that the centre of the town has moved slowly northwards away from the desert and towards the mountains throughout a fairly long history. However, this apparent progress northwards of the salinity and the desert and the resultant decrease in the amount of cultivable land around Jajjarm, although it is a natural process under conditions of intensive irrigation, provides no immediate answer to the problem of its decline, since there is still land far in excess of the amount of water available for irrigation.

Other smaller Islamic mounds and graves spread over a large area of unwatered land attest the prosperity quoted in some of the old travellers for the district of Arghiyān.

\section{Communication}

Unfortunately any information about the region in prehistoric times will have to await scientific archaelogical excavation. Although at the present time this enormous plain cannot boast a single road, but only a few barely " jeepable" tracks, it used to carry a main west-east highway. Owing to the pattern of motor road development in the last quarter century or so, the entire plain has become suddenly isolated from the main arteries of communication. The completion of the railway connection to Mashhad in 1958 , which passes roughly through the centre of the plain was a step towards remedying this situation. But the railway is no substitute for a road, and anyway only serves the Kalāt-hā and Juvain directly, while Jajjarm is doubly cut off from it for some six months of the year by the swamp at the entrance to Juvain, and the Kāl-i Shūr. It is interesting and I suggest typical generally of the ecology of Persia that these four natural divisions look not across the open plain at each other, but, at least more immediately, over to the other side of the mountains under which they shelter and to which they owe their meagre water supply. Juvain looks to Sabzavār, Isfarāyin to Bujnurd, Jājarm to Bujnurd and Gunbad-i Qābūs. ${ }^{8}$ Centres of plains on the plateau are often saline, waterless and some-

\footnotetext{
' I am grateful to Mr. D. B. Stronach for this evaluation of the pottery I collected there.
}

\footnotetext{
- Only recently, in the era of motorized transport, the pull of the capital has greatly increased traffic from Isfarāyīn to Sabzavār, and from Jājarm to Shāhrūd.
} 
times treacherous; mountain ranges are invariably dissected by river courses which are passable for most of the year. Modern administrative divisions are here and often drawn through the centres of plains-not along ranges of mountains. The real line of demarcation in this area is the Kāl-i Shūr, a perennial but hopelessly salt and useless water course-except for a few fresh springs near its source, which however are not suitable for agricultural use. It flows through the middle of the plain and separates in the east-west section of its course the Bujnurd region from the province of Baihaq, and, when it turns south, Khurāsān from the west.

The earliest information available about routes in the area is from Ibn Khurdädbih (864 A.D.), who with all the earlier itineraries describes the main west-east road as passing through Mazinān and Sabzavār. ${ }^{9}$ This has probably always been the post route, and is, of course, slightly more direct. It is attracted away from the plain by the richer region of Baihaq, which, since it would appear always to have supported a centre somewhat bigger than anything in the plain to the north of it, compensated for the long, exposed march (over 250 kilometres) over waterless desert from Bastām. Le Strange, in his synthesis of the geographies, describes (without clear references) two routes from Bastāam to NIshāpūr. " The more direct, the post road, lies along the edge of the desert, going through Sabzavār. The longer caravan road is to the north, and curves through the great upland plain of Juvain which is separated from the Great Desert by a range of hills." 10 In the middle of the eleventh century, Baihaqi records that "Amĩr Mas'ūd proceeded from Nīshāpūr to Gurgān via Isfarāyin ". ${ }^{11}$ It is not clear from the context whether Mas'üd would have been travelling by the main route or not. The journey was made in the winter and there was a strong cold wind. ${ }^{12}$ It is surprising that Isfarāyin is specially mentioned, but there is no mention of any place between Isfarāyinn and Gunbad-i Qābūs ("Turbat- $i$ $Q \bar{a} b \bar{u} s ")$. At the beginning of the thirteenth century we know from Yāqūt that caravans from Basțām to Nishāpūr passed through Juvain, ${ }^{13}$ presumably therefore missing both Sabzavār and Isfarāyin, though very likely calling at Jājarm if only for the sake of water (for a direct route from Āzādvār to the Kalāthā or Mayāmay would in present conditions present water supply difficulties for a caravan). This was in fact the case in the mid-fourteenth century when Mustauf I wrote. According to him, the caravan route passed through the following stages: Basțām to Maghz - 7 parasangs; then Dih-i Sulțān 7 parasangs; Rabāṭ-i Savanj 3 parasangs; Jājarm 6 parasangs; then south across the Kāl-i Shūr and the stretch of kavir to Āzādvār 8 parasangs; and thence through the Juvain corridor to Nīshāpūr, totalling $6_{5}$ parasangs in all from Bastām to Nishāpūr ${ }^{14}$-in fact only some 2 parasangs longer than today's motor road. Rabāt-i Savanj is now known simply as Rabāṭ or Rabāṭ-i Jājarm-since now of course nobody passes through it except to go to Jājarm, for there is no longer any through traffic. Again there is no hint that they called at Isfarāyiñ.

At the beginning of the fifteenth century (1403-04) Clavijo stopped at Jājarm on the way to Timur's court. He was immediately provided with fresh horses and was well impressed by the fact that Timur had built caravanserais and kept good supplies of horses at post stops along the route right up to Samarqand. ${ }^{15}$

Finally, Nāṣiru'd-Dīn Shāh Qājār, on his pilgrimages to Mashhad, camped at Jājarm (1283I 300 A.н.). The Mirätu'l-Buldān and the Matla'u'sh-Shams (I 3 I A.н.) give us two routes: one the old southern post road through Sabzavār and the other from Basțām north to Nardīn, east to Jājarm, and on to Mashhad via Sankhāṣ and Bujnurd, ${ }^{16}$ - which surely reflects the decline of all parts of the plain and the rise in importance of Bujnurd under the Shädlu kurds who had been moved up to the Atrak by Shāh 'Abbas. Jājarm is the only section of the plain left on a main route, and Jājarm was also, according to Curzon, ${ }^{17}$ included in Shāh 'Abbās' road from Gurgān to Mashhad, but in Qājār times at least this would seem to be due merely to its position half way between Bastām and Bujnurd rather

\footnotetext{
- Le Strange, Lands of the Eastern Caliphate, 1930, p. 430.

10 Ibid., p. 39I.

11 Tärikh-i Bayhaquĩ, Tehrān, 1324 AHS, p. 448.

12 This strong wind is of frequent occurrence in the plain and may occur at any season. Once it rises it normally takes about five days to blow itself out. In the summer the peasants wait for it for the winnowing.

Yāqūt, op. cit., vol. 2, p. 192.
}

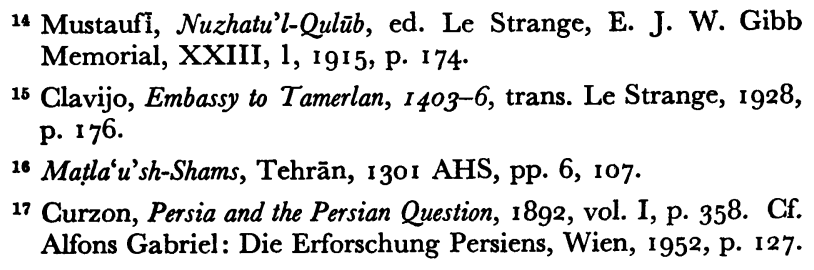

${ }^{14}$ Mustaufi, Nuzhatu'l-Qulüb, ed. Le Strange, E. J. W. Gibb Memorial, XXIII, 1, 1915, p. I 74 .

15 Clavijo, Embassy to Tamerlan, $1403-6$, trans. Le Strange, I928, p. 176.

16 Matla'u'sh-Shams, Tehrān, I301 AHS, pp. 6, 107.

${ }^{17}$ Curzon, Persia and the Persian Question, 1892, vol. I, p. 358. Cf. Alfons Gabriel: Die Erforschung Persiens, Wien, 1952, p. 127. 
than to any attraction in the town itself. Jājarm then, having entered written history as an entrepôt at a major cross-roads, had dwindled in the nineteenth century to being simply a village on the way, so that when it came to defining distinct lines of communication for motor traffic in this century the whole plain was left isolated and the district of Arghiyān, in particular, stranded.

\section{Historical}

In pre-Mongol times Jājarm is clearly stated to have been a frontier borough on the road to Gurgān from Nīshāpūr, and the emporium of Gurgān as well as Qūmis and Nishāpūr. It was situated within the confines of the district of Nishāpūr. ${ }^{18}$ Our plain therefore carried the commerce of three provinces, which met in Jajjarm, and the whole eastern part of the plain despite its barren character naturally prospered by this. Though no longer prosperous, it is still a frontier borough and it is not quite certain to which province it should belong. For Mashhad is almost as far to the east as Tehrān is to the west, and Shāhrūd is no less accessible than Bujnurd.

The pre-Mongol sources in general speak well of the plain, though unfortunately not often in any concrete terms. In the Hudūdu'l-'Ālam (982-983 A.D.), Āzādvār was a pleasant borough in the desert on the road to Gurgān. ${ }^{19}$ In Muqaddasi ( 985 A.D.) it was the chief town of the Juvain corridor, which was very fertile in foodstuffs. ${ }^{20}$ And in Yãqūt (1225) it was populous and had fine mosques, and outside its gate was a great khän for merchants, for its markets were much frequented. The gardens of its villages stretched continuously all down the valley and the water for their irrigation was brought by underground water courses from the springs in the southern hills. One hundred and eighty-nine villages were dependent on it. ${ }^{21}$ Muqaddasi describes Isfarāyinn as growing much rice [sic !] and fine grapes. It was very prosperous and had good markets. Jäjarm had a fine Friday mosque and was a well-fortified city with seventy villages dependent on it. ${ }^{22}$ Arghiyān contained seventy-one villages, and Jājarm, now strangely mentioned separately from Arghiyān, had many villages-some of which are in the range overlooking Āzādvār - an area which is now deserted. ${ }^{23}$ Āzādvār was still the main centre of Juvain.

The next detailed mention comes in Mustaufi in the middle of the fourteenth century. The Mongols had passed through, but apparently without very serious results. The capital of Juvain had changed to Furūmad (then spelt Fariyūmad), which is in fact not in the Juvain plain at all, but some miles south of the western end of it, and separated from it by the beginning of the Jughatay range. It used to be part of the tumān of Bayhaq, but is now independent (mufarrad). Isfarāyīn, which was ravaged by the Mongols in $1220,{ }^{24}$ had now become a city of medium size with nearly fifty dependent villages and a strongly fortified castle to the north.$^{25}$ In the middle of the fourteenth century it was for a while brought under the control of the shortlived Sarbadar dynasty in Sabzavar. ${ }^{26}$ When Clavijo passed through on his way to Samarqand in the summer of I404 Isfarāyin was a very fine place with many fine buildings, both private houses and mosques, but " all is now for the most part without inhabitants!'”27

Mustaufĩ describes Jājarm as a medium-sized town, and since for one or two days' journey all round the pasturage was of a poisonous herb, it was quite impossible for any army ever to approach the place. This poisonous herb still exists north of Jājarm over a fairly wide area and shepherds have to be very careful that their flocks do not stray near it, but it does not grow in any other quarter and the assertion that no army could ever approach Jājarm because of it should perhaps be attributed to Mustaufi's love of wonders. He also mentions a strong castle in Jajjarm, and says that there are many villages dependent on Jājarm, and that houses are not easily obtained within the town. Crops of corn and fruit were abundant. ${ }^{28}$ A little later (in ${ }^{3} 376$ ) the castle of Jajjarm was taken together with that of a village in

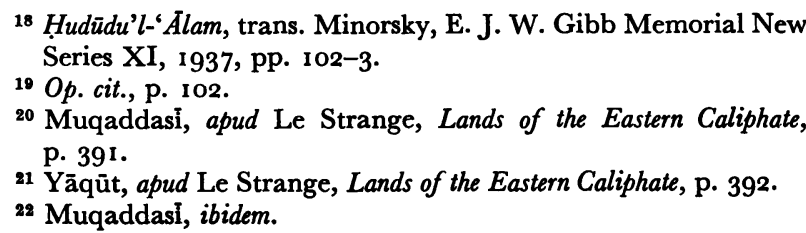

18 Hudūdu'l-'Alam, trans. Minorsky, E. J. W. Gibb Memorial New eries XI, 1937, pp. 102-3

Muqaddasi, apud Le Strange, Lands of the Eastern Caliphate, ${ }^{22}$ Muquaddasí, ibidem.

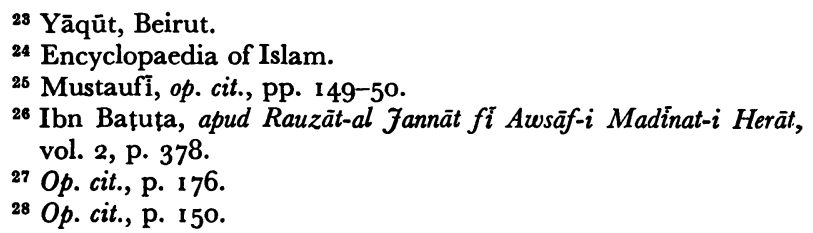

${ }^{23}$ Yāqūt, Beirut.

Ibn Bațuța, apud Rauzāt-al Jannāt fí Awesāf-i Madinat-i Herāt

27 Op. cit., p.

${ }^{28}$ Op. cit., p. ${ }^{1} 5^{\circ}$ 
Juvain. ${ }^{29}$ A little later still Clavijo gives the following account of Jājarm: " The town stands in a plain at the foot of some bare mountains, and from these they have tunnelled conduits to bring the water down. Standing in the middle of the town there is a castle crowning a low hillock artificially built up on clay foundations and the town itself has no wall round it. During the past winter much snow had fallen, and this, when the summer heat had set in, had melted and flooded the water conduits. A freshet had recently come down, and half the town had been destroyed by the waters, which too had overwhelmed the castle ! Further the floods had drowned out all the corn lands ...".30 Despite this, Clavijo's company with their royally appointed escort were immediately provided with fresh horses. During the Mongol period, therefore, unlike the rest of the plain, the Jājarm area would seem not to have declined, but rather to have grown in importance and prosperity-perhaps at the expense of Isfarāyin. But if this is true, the reasons are obscure. In the Zinatu'l-Majälis, written in I595, IsfarāyIn is still described as a middle-sized town, but would appear to have been destroyed again by the Uzbegs shortly after this. ${ }^{31}$

At the beginning of the eighteenth century we learn from the Tazkiratu'l-Mulūk that Āzādvār was again the main centre in Juvain, but that the district of Juvain was much less important than Isfarāyinn. ${ }^{32}$ According to local tradition, recorded by Yate in I90o, Isfarāyin was again destroyed by the Afghans, and, when he passed through, the ruins of the old town were still visible and extensive and adjoined the new town. ${ }^{33}$

A hundred and fifty years later there is an interesting Collection of Fournals and Reports by Capt. the Honourable G. C. Napier, who travelled extensively in the area and published his notes in 1876 . He refers often to a serious drought and consequent famine which had recently afflicted the area. In Furūmad the famine had emptied a hundred houses and the ruins were visible in every direction. The town of Jughatāy (which had now displaced Furūmad and Āzādvār as the most important centre in Juvain) contained the stronghold of the chief of Juvain, Allāhyār Khān, who, with his brother, Ja'far Khān, had held all the country as far as Mazinān and Sabzavār, but was defeated by Fatḥ'Alï Shāh in person shortly after the latter's accession. The town was nearly destroyed by the famine, and only about a hundred houses remained occupied. For more than a mile around the village of Sankhāsthe principal of a group of four villages - the ground was covered with remains of ruined houses and walled gardens. However, Napier writes that on enquiry he was told that " the evident decrease in population was not due to the famine, for it had fallen lightly on these villages. The fine springs forming the source of their water supply had not been materially affected by the three years' drought, but had continued to yield sufficient to irrigate the village lands and to support the population. The true causes are obscure, for within the recollection of the predecessors of the present oldest inhabitant, from whom I received the information, Sankhās numbered $75^{\circ}$ houses, it has now only 200."34

Famine, particularly as the result of drought, is not a rare phenomenon in Persia. The main feature of the precipitation pattern in Khurāsān-in so far as we have enough figures to judge-is its variability and unreliability ${ }^{35}$ It is reasonable to assume that subsistence farming has been progressively increasing since the Mongol invasions, simply because of general insecurity, particularly outside the cities. A small settlement tending to farm at subsistence level, when faced with the inevitable drought of several years, will stand little chance of pulling through intact, or even reattaining its former level of prosperity, except by the efforts, expense and investment of a powerful man with a direct interest in the village community and its land. From the written evidence available there is every reason to suspect that such conditions did not obtain for the villages in the plain.

Between Sankhāṣ and Jājarm, besides two or three springs at the foot of the hills, Napier found no potable water. Mounds of ruined qanats here and there proved the existence in former times of villages, but the waste was then abandoned to the wild ass and the gazelle and the Turkoman raiders, who had probably been the main instrument in reducing it to its present state. Nevertheless, he continues, for

\footnotetext{
${ }^{29}$ Rauzät-al-Fannāt fi Awsäf-i Madinat-i Herät, vol. 2, p. 33 .

${ }^{30}$ Op. cit., p. 176.

s1 Encyclopaedia of Islam.

${ }^{32}$ Tazkkiratu'l-Mulük, trans. Minorsky, E. J. W. Gibb Memorial, 1943, p. 103.
}

\footnotetext{
${ }^{83}$ C. E Yate, Khorasan and Sistan, 1900, p. $3^{83} \mathrm{ff}$.

${ }^{34}$ Pp. 25, 26, 7I, 73 ff.

${ }^{35}$ A Preliminary Assessment of Potential Resources in Khurasan Province, Iran, K. S. McLachlan and B. J. Spooner, Italconsult, Rome, I963.
} 
many months past, the road had been as safe as roads in Persia usually are. Small parties of thieves lurked about the hill skirts, but the extensive ravages of former years had ceased.

Jajärm was a small straggling town of 400 houses. "In the centre of the town is one of the high circular mounds, so frequently met with in northern Khurāsān, surmounted by the ruins of a mud fort of not very ancient date. It bears the name of Ali VerdI Khān, the first chief of the Giraili Turks settled in the country. A small Imāmzādeh, lying a mile to the south east of the walls, contains a tomb covered with large blue tiles, on which are verses from the Qur'ann. . . For some miles to the south the ground is covered with fragments of small red brick and blue glazed tiles, indicating the site of one of the towns founded after the Arab occupation.... Three miles to the north-west is a stone fort crowning a low isolated lime stone rock in good preservation. ... The rock within the walls is pierced by a shaft to a depth of about Ioo feet, from which it is said a communication exists with the village of Garmeh, half a mile to the west. That the excavation was never of use as a well was evident from the remains of a number of large earthen vessels built into the foot of the outer wall which could only have been provided as receptacles for storing water. The only coins known to have been found are some silver pieces stamped (it is said) on one side with the usual inscription of the Khalifat, on the other, with the name of the city of Jajjarm. ${ }^{35 a}$ There are no other visible traces of remains other than those of a small town of the period of Arab occupation, the dispersion of fragments of masonry to so great a distance being accounted for by the fact that the plain is liable to sudden inundation from the mountains to the north.

" That the present population of Jājarm, four hundred families, is only a remnant, is clear from the great extent of the old walls; in the time of Nādir Shāh there were some 5,000 families [sic ! $],{ }^{36}$ and as late as the reign of Fath'Ali Shāh, the town furnished 200 men to the regiment known as the Lashkar-i 'Arab va 'Ajam. Its decline is attributed entirely to the Turkomans, who after the death of Nādir devastated the country, destroying the irrigation works by which only so large a population could have been maintained. The mounds of numerous qanäts, now dry, surround the cultivated area. With the water supply at the present time available, the crops raised are insufficient for the inhabitants, who import largely from Shāhrūd and the Gurgān plain, supplying in exchange salt obtained from the water of the Kāl-i Shūr, a briny stream flowing through the plain to the south. The scanty revenue of the ' belūk' of four villages-Jājarm, Garmeh, Iver, and Darreh, ${ }^{37}$ in all seven hundred families-is entirely devoted to the maintenance of one hundred horsemen for border defence. These are to a great extent mounted by the Elkhān of Bujnurd, who relies on them to hold the passes north of the town."38

Shortly after Napier, Colonel C. M. MacGregor passed through the plain, and noticed there remains of an old wall much beyond the then limits of Sankhāss suggesting it had once been much larger than the 200 houses it then contained. "The whole country around", he writes, " is very much exposed to Turkoman raids and consequently the whole plain is dotted with towers of refuge, which are speaking monuments of the havoc committed by these wretches." MacGregor thought that the village of Jajjarm " may contain three hundred houses, though there seems to be more. It boasts a good deal of cultivation some of which is dependent on rain and some on water brought by Karezes from the hills. Nearly the whole plain on which this cultivation is situated is covered by Turkmun towers, showing what a dangerous spot this is . .."39 The Turkoman entered the plain by a ravine, known as Gudär-i Gazi to the north of Jajjarm, which carries perennially a small amount of water through the first range from a valley behind.40 Their main objective was the main road between Mayāmay and Mazinnān which they reached in one waterless stage from the spring at Kūh-i Bābā.

5a Mongol coins from Jajarm are quite numerous, but few have
been published. For examples see the Catalogue of the Oriental
Coins in the British Museum by S. Lane Poole, vol. VI, pp. 66
and IOI. There are unfortunately no published sour ces for
determining the life of the mint. Coins minted at Isfarayin
under the early Safavids are cited in Coins, Medals, and Seals of
the Shahs of Iran (I500-194I) by H. L. Rabino di Borgomale
(1945). (I am indebted for these references to Dr. A. D. H.
Bivar.)
36 Napier gives no source for this astounding assertion, and is therefore most likely repeating exaggerated tales of former prosperity heard on the spot.

37 Iver and Darreh are within a parasang to the west of Garmeh. 38 Op. cit., pp. $73 \mathrm{ff}$.

39 Narrative of Fourney through the province of Khurasan and on the North West frontier of Afghanistan in 1875, Colonel C. M. MacGregor, vol. II, I04 ff.

40 Most of this water sinks into the plain as soon as it leaves the mountains, but a certain amount of it is carried in a jüb to a patch of cultivated land not far from Jājarm. 
Of the three main Persian sources on the area for this period-the Mir'ätul-Buldān, Nāsiru'd-Din Shāh's Journey to Khurāsān, and the Matla'u'sh-Shams-the last gives the most comprehensive and detailed description of Jājarm. On his pilgrimages to Mashhad Nāșiru'd-DIn Shāh passed only through that part of our plain which used to bear the name Ārghiyān, on a route: Basțām, Nardin, Garmeh, Jājarm, Sankhās, Bujnurd, on which Jājarm marked a stage. The Matlla'u'sh-Shams was compiled by Sanf'u'd-Dauleh from what was observed on the second of the Shāh's pilgrimages in the year 1300 A.H.Q. At this time Garmeh contained 200 peasant ( $\left.r a^{6} \hat{i} y a t\right)$ families, a hammäm and a mosque. There is mention of the qal'eh-i Falälu'd-Din which is described as being built of stone, brick and plaster ( gach), and having six turrets (burj) and several rooms (chand yurt). The well-shaft inside was filled in to a depth of twenty $z a r^{6}$, and it is suggested that it was originally meant simply for storing water brought up from the spring, whereas the cisterns on the outside were perhaps for flour. The spring at the foot of the hill on which the qal'eh is situated, is estimated to have a flow sufficient to turn five millstones (panj sang $\bar{a} b$ ) in the summer, of which two-thirds was crown property (khäliseh-i divann) and one-third belonged to the peasantry. "Jajjarm itself was once more prosperous than it is now. It is now a reasonable town with a fort and turrets and extensive gardens." The town is encompassed by a fortified wall and details of the turrets are given. Seven quarters are named within the town, and the population is made up of ten distinct descent groups (țāyifeh). Two of these are Giraili Turks who claim to have come from Kālpūsh (in the mountainous country to the north-east) during the reign of Āghā Muhammad Shäh, one is from Ganjeh, another is "Arab from the 'Persian Arabs' (Arab 'ajamha $=$ Persian pastoral nomads ?) of Shāhrūd and Basțām"; a fifth are Uzbeg from Khẉārazm; a sixth from Bukhārā; a seventh are sayyids; the eighth are Fakhrāni; the ninth Häjjis; and the tenth dihqänhā or peasants. The governorship used to be invested in one of the Giraili groups. ${ }^{41}$

We may presumably interpret this to mean that there were eight tribal elements of comparatively recent appearance, the peasants and $h \bar{a} j j \bar{i}$ s being descendants of the peasants, small landowners and merchants of the old population. The new tribal élite would naturally refer to these sections as other tribes.

There are seven mosques, a fine caravanserai and a good hammām. The "Friday mosque" is very old and large enough to take 200 men. Two shrines are mentioned: one over the grave of an 'All ibn Maḥziyār (Muhammad Ziyār) known as Khwājeh Maḥziyār, which prospers (ba kullī ābād ast); the other which is in ruins is known as Khwājeh Kamāl. Its ruin was being accelerated by the peasants, who, as they often do, were carrying away its building materials for use elsewhere. There are also remains of several other shrines.

Eight qanāts are named as serving Jājarm and the neighbouring small villages. The products are wheat, a little rice, a few types of tree fruit, melons, etc. Gazelle, wild sheep, and wild ass were to be found in the plain still, and Nāșiru'd-Din Shāh was very keen to hunt. The flats on either side of the Kāl-i Shūr provided salt for Gurgān, Bujnurd and Juvain.

Most of the streets in the town had been paved with rough stones, but were now in disrepair through lack of attention. Three millstones existed in the town of a size far too large for any of the existing mills. The author was at a loss to explain their existence, as were the local people. Sani'u'd-Dauleh records that Jājarm had been once a part of Basțām, once of Astarābād, and then in the reign of Fatḥ'Ali Shāh when Ismā'îl Mīrzā was governor of Shāhrūd and Basțām it became part of that province. When Muhammad Shāh came to Kālpūsh he made Jājarm part of Nardīn. . . . Now it was part of Bujnurd, whereas at one time Bujnurd had been part of Jājarm!42

In 1900 another traveller, C. E. Yate, records that Jajjarm contained about 500 houses, and that the $\mathcal{N} a y i b$ or governor's deputy was still a Giraili. The area was badly supplied with water, and what there was was used up in the growing of $\operatorname{cotton}^{43}$ for export to Russia through the Armenian traders in Sabzavār. The village did not even grow sufficient grain for its own consumption and the silk industry it formerly possessed had quite died out.

11 Matla'u'sh-Shams, vol. I, $107 \mathrm{ff}$.

4 Ibidem. The sudden surfeit of detail, when the relative importance of the area has obviously diminished, provides an interesting sidelight on the Qājār régime.

13 Author's italics. 


\section{The Present}

There is much in the story of Jājarm which, put in general terms, would seem to be typical of much of Persia-particularly the eastern provinces. It is perhaps not possible to date the peak of prosperity, but the decline is obvious, and its relation to the change in the pattern of communications. It is tempting to interpret the evidence to mean that there used to be far more water than there is now. That rice could have been grown in Jājarm now seems astonishing, but it was probably never grown on any scale, and was simply a means of making use of what water there was during the summer after the wheat had been harvested. Cotton, a cash crop, has now taken its place.

The nadir of decline was probably touched only a few decades ago. Since then a slow upward trend has begun which is probably entirely due to Westernization and (comparative) ease of communication with the capital. The people can still name the seven quarters (mahall), each of which appears to be dominated by one or more extended families. However, the change is obvious, and the word " țāyifeh" is no longer heard.

For Jājarm, of course, Westernization is really "Teheranization". On the one hand there are new laws which affect the status quo. A very obvious example is Land Reform. On the other hand, there are efforts to change the appearance of the town. For example, all towns must have a khiyäbäna broad, straight, main street. To build the khiyäbän means destroying many houses and so changing the pattern of some of the quarters. When it has been built, those of the population with more contact with Teheran and other towns start to want houses on the khiyäbann, and the traditional relationship between kinship and neighbourhood begins to break up. For though this is a sedentary community and Jājarm has a long history, most of the more wealthy and powerful members of the present population came to Jajjarm not so very long ago, since the Mongol invasions, and came organized on tribal lines. There is a definite connection between this tribal origin of the more influential part of the population of Jajarm and the general insecurity of the area up until very recent times. Jajarm is situated at the northern edge of the eastern side of the plateau which is Persia proper, and its situation guards two main ways of access on to the plateau. It must therefore have suffered the maximum effects of any border insecurity in the north-east of Persia throughout its history, and the invaders have invariably been tribal. The two most influential sections of the population now are known as the Näyibiha and the Sādāt. We know from Yate that at the end of the nineteenth century the Nayib was a Giraili. But many of the Nāyibihā are offended at the suggestion that they are therefore Turkish, and protest that they came from Ganjeh. We may perhaps therefore assume that the Ganjeh-i and Giraili tribes mentioned in the Matla' $u^{\prime}$ 'sh-Shams have intermarried to the extent that they no longer distinguish between each other, and so far as the present politics of Jajjarm are concerned have become one element. The same would now appear to be happening between the Nāyibỉhā and the Sädāt. They are already intermarried to a high degree, but are kept apart for the time being by rivalry for official posts in the municipality.

However, the number of people remaining who can name three or more ascending generations is few. The basis of former wealth-land and water-is no longer secure. The distinction with the " dihqānha" - perhaps descendants of original, non-tribal, peasants-is disappearing. And so the pattern of personal relationships in the tribal elements gradually becomes that which is typical of the normal cognatic peasant society, and alien wealth and status values replace traditional ones.

The present population is reckoned to be about 5,500 or 800 households, of which some 30 per cent own some land either around Jājarm itself or in the lower part of Juvain. Dasht in the north-west is largely owned and settled by Jājarmis, and many Jājarmis emigrate to Similqān and the Gurgān plain. There has been no immigration to Jajarm for a long time. Apart from agriculture most of the people in Jajjarm own or have some interest in flocks, and the main pasturage areas are along the upper part of the Kāl-i Shūr, the lower end of the Juvain corridor, and to the north-west towards Dasht-nowhere less than nine miles from Jajarm. Exports from the town, in a good year, consist of cotton, fruit, wool, dairy products and some corn.

Any conversation in Jājarm sooner or later turns to the subject of water. There is any amount of land to be cultivated, but no water to irrigate it. As much as two-thirds of the town's total water supply 
comes in an open $j \bar{u} b$ three miles across the desert from the spring at the foot of Qal'eh-i Jalālu'd-Din. There is only one good qanät. Another one which was started recently has hit conglomerate rock and although its yield is good so far, it has become uneconomic to proceed with it. Any water tapped from the south or east of the town draws from the Kavir and is saline. East of north the ground slopes away and so does not allow the construction of a qanät. Was there more water in prehistoric or medieval times? The Nuzhatu'l-Qulūb in its fantastic way tells of a mountain in the "neighbourhood of Jajjarm which rises like a perpendicular wall and from the midst of this mountain wall three springs burst forth side by side, each sufficient in volume to turn a millwheel. For the space of an arrow flight they flow as through a spout, and then serve to irrigate many of the lands of Jajarm, and of the neighbourhood. The length of the stream is twelve leagues ".44 Legends of this nature are still alivein Jajjarm and serve further to frustrate the present population, and expensive efforts and expert opinions in the last few years ${ }^{45}$ have not succeeded in finding any untapped sources of any significance.

Clavijo witnessed severe floods when he passed through Jäjarm, and this is a phenomenon which has to be reckoned with over much of the plateau, particularly in the spring. Enormous quantities of water released by cloudbursts pour off the mountains across the plains and disappear again into the desert as quickly as they had come. In some parts" a certain amount is caught behind a "band" or improvised dam and, allowed to sink through, after which a good crop can be grown on the land. But since Clavijo does not mention any such arrangement, it would not seem that Jajarm ever took any advantage of flood waters in this way. The problem remains unanswered, but a very large extent of Jājarm's former prosperity must have been due to its position on important trade routes which now bypass the whole plain. ${ }^{47}$

The borders of Arghiyān, or the area dependent on Jajjarm, to the south seem to have varied little, but to the north-through the mountain and valley systems which mark the end of the plateau-in the periods of its prosperity extended beyond Similqān and eastwards towards Bujnurd to include whatever settlements sought its protection. But Jäjarm never appears to have been an important provincial centre and nor does anywhere in the plain. Perhaps Miyānābād is on or near the site of the largest town the plain has held. This plain is in many ways typical of the areas into which the settled part of the Persian plateau may be divided. It is for the most part dry and barren. It has at times supported a much larger population than it does now, but shows some improvement now on the beginning of this century. The pattern of settlement in it tends to hug the base of the surrounding mountains, except in cases where the lie of the land allows the qanats to tap more water if the settlement is further out in the plain. The villages rely for their prosperity on irrigation works which are expensive and complicated. These have fallen into disuse owing to lack of political and social security-special factors in this area being the Turkoman raiders on the one hand and on the other: the lack of any one landowner powerful and wealthy enough to provide the investment to start things going again-even if he had felt secure enough to make it worth his while. However, this area is somewhat unusual in that it has never had a real focal point within it. The influences on it have always been centrifugal rather than centripetal, which makes its plight all the more serious in the context of the present communications system, for there is no longer anything to bring people to the area. An interesting indication of this condition is the number of names of distinguished men which can be read in histories and anthologies ending in the nasab: Arghiyāni, Jājarmí, Isfarāyīnĩ, Jughatā-ĩ, and of course Juvaini. But none of these men made their reputation in the plain they were born in, and very few, if any of them, returned to it to die.

Jājarm is a bakhsh situated roughly half way between Khurāsān, Gurgān and what used to be called Qumis. At various stages of its history, it has been subordinate in turn to each of the larger centres

44 Op. cit., p. 228.

45 In $195^{8}$ Jājarm officially became a shahr (town) with an anjuman (council) and a shahrdär (mayor = executive officer of the anjuman). This made it possible for the first time for programmes to be undertaken in the name of the town. The main aim of the shahrdār (who is one of the Sādāt: the hisäbdär-i shahrdāri is from among the Nāyibīhā) from the start has been to increase the town's water supply.
46 E.g. Baydukht in the Gunābād plain. In the enormous plain west of Küh-i Taftān in the sarhadd country of Balūchistān there are many remains of this type of band, which are, however, no longer used in the area. In mountainous country they are found in the $Q \bar{a}$ 'ināt, and the Makrān range.

47 Similar arguments for other areas are presented in Between Oxus and Jumna, Arnold J. Toynbee, O.U.P., I96r. 
which surround it: Basțām (Shāhrūd), Baihaq, Nishāpūr, Nardīn (eight parasangs to the west) and Bujnurd to which it now belongs, because the main land owners of the area have for some time past been Shādlū Kurds who live in Bujnurd. There is now talk of applying to be attached once more to the shahristān of Shāhrūd, because of the decline in the influence of the landowners and the pull of the capital.

Water and roads are the two outstanding needs of the region. The people of the area feel, reasonably, that they have been left out of the present social revolution in Iran. They have done little to help themselves, and talk of lack of confidence in the future, although justifiable, cannot be accounted the sole reason for the absence of minor investment activity and agricultural improvement. The individual's solution is migration: to Tehrān, or the Gurgān plain. There is little interest in Bujnurd or Khurāsān in general, for in Persia everywhere one looks towards the capital. But no ordinary Persian villager lightly exchanges the dry climate of the plateau for the damp lowlands, or the freedom of village life for the commotion of Tehrān. With a little government investment, it would probably not be difficult to halt the migration and even attract back some of those who have migrated in recent years. But the only real answer lies in communications. The obvious route now for a road through the plain is Bujnurd-Jājarm-Shāhrūd.48 Automatically Jājarm would once more become an important stage on an important road-from the north-east to the capital, and in a new ecological and economic context might perhaps manage to resume its former function and prosperity.

${ }^{48}$ Cf. K. S. McLachlan and B. J. Spooner, op. cit., p. $4^{0 .}$ 